\title{
'Greenwashing' tobacco products through ecological and social/equity labelling: A potential threat to tobacco control
}

\author{
Frank Houghton', Sharon Houghton'², Diane O' Doherty', Derek Mclnerney', Bruce Duncan³
}

\begin{abstract}
There has been significant growth in ecological/environmental labelling of products and services internationally in recent years. Such efforts have become an integral element of the marketing strategies used by many firms. Concerns have been raised, however, that for some companies, this is little more than 'greenwashing', i.e. a cynical attempt to boost sales without any meaningful underlying sensitivity or change, in practice. Given the extremely negative track record of the global tobacco industry (Big Tobacco), it is essential that health policy makers and anti-smoking campaigners closely monitor this industry's attempts to exploit both growing environmental concerns among consumers and gaps in legislation. Although there is relatively strong legislation in some countries, to prohibit suggestions that cigarettes may be environment friendly, a further tightening of legislation is required.
\end{abstract}

\section{AFFILIATION \\ 1 Department of Applied Social Sciences, Limerick Institute of Technology, Moylish, Limerick, Ireland \\ 2 University of Limerick, Limerick, Ireland \\ 3 Hauora Tairawhiti, Gisborne, New Zealand}

CORRESPONDENCE TO

Frank Houghton. Department of Applied Social Sciences, Limerick Institute of Technology, Moylish, Limerick, Ireland. E-mail: frank.

houghton@lit.ie

KEYWORDS

tobacco, greenwashing, ecological labelling, environment, advertising, marketing

Received: 28 September 2018 Revised: 30 Octomber 2018

Accepted: 9 November 2018

\section{COMMENTARY}

Tobacco related deaths continue to constitute the largest cause of preventable mortality globally ${ }^{1,2}$. Estimates of annual global deaths from tobacco related disease have grown from six million to seven million, with projections of eight million by $2030^{3}$. Such estimates routinely underestimate the actual impact of tobacco, as they ignore both morbidity and the financial consequences associated with smoking, as well as the opportunity cost of tobacco production and purchase $\mathrm{e}^{4,5}$.

However, one aspect of the global tobacco industry that is often underplayed is its adverse environmental impact $^{6,7}$. Although health researchers routinely understand this in terms of seconhand ${ }^{8}$ and thirdhand smoke $\mathrm{e}^{9,10}$, there is a wider environmental context to such discussions. Significant adverse environmental impacts of the tobacco industry involve: fertilizer and pesticide use; deforestation; water use; waste ${ }^{11}$; transportation and pollution; and packaging ${ }^{6,12}$. Particular attention from an environmental perspective has focussed on the impact of cigarette butts $^{13-16}$. The adverse impact of the global tobacco industry has been addressed repeatedly by the World Health Organisation (WHO) $)^{6,17}$, and is specifically addressed in Article 18 of the Framework Convention on Tobacco Control (FCTC) ${ }^{18}$. Recent attempts to quantify the significant negative impact of the global tobacco industry include an assessment by Zafeiridou et al. on behalf of the WHO Framework Convention 
on Tobacco Control (FCTC) ${ }^{17}$. This research indicates that globally 'the tobacco supply chain contributes almost $84 \mathrm{Mt} \mathrm{CO}_{2}$ eq emissions to climate change, 490000 tonne 1,4-DB eq to ecosystem ecotoxicity levels, over 22 billion $m 3$ to water and $21 \mathrm{Mt}$ oil eq to fossil fuel depletion annually ${ }^{\prime 17}$. Given increasing environmental controls in many Western countries, there has been a move to production in poorer, less regulated countries in recent years ${ }^{17,18}$.

The global tobacco industry (Big Tobacco) has been likened to the many-headed hydra of ancient Greek mythology ${ }^{19}$. According to legend, as one snakelike head was cut-off, two immediately sprouted to replace it. Given the increasing regulation of tobacco in many Western countries (excluding the USA) ${ }^{20,21}$, and given their history of corporate malfeasance ${ }^{22-33}$, it seems extremely likely that Big Tobacco will exploit any potential tactic to maintain or increase sales ${ }^{34-36}$. This Machiavellian approach to marketing exhibited by Big Tobacco may be significant in the context of the growth in identity/values-based purchasing and investment in recent years, which has resulted in a significant increase in value-based labelling of goods and services ${ }^{37-40}$. This may be seen, perhaps most publicly, in certain aspects of the global fashion industry ${ }^{41-44}$. Such labelling usually covers the domains of social justice, animal welfare or environmental/sustainability issues ${ }^{45}$. For example, social-justice/equity-based labelling would include well known labelling such as Fair Trade ${ }^{46}$, as well as GoodWeave $^{47}$, Child Labor Free ${ }^{48}$, RugMark ${ }^{49}$, and Conflict Free Diamonds ${ }^{50-52}$. Animal welfare labelling would include labels such as Free Range ${ }^{53}$, The Body Shop ('cruelty free and forever against animal testing' $)^{54}$ and Dolphin-friendly tuna ${ }^{38,39}$. Examples of environmental and sustainability labels would include Organic $^{55}$, GMO Free ${ }^{56}$, Sustainably Sourced ${ }^{57}$, and Recyclable/made-from-recycled-material ${ }^{58}$.

In assessing the potential appeal and impact of such labelling, it is vitally important to note the impact of branding. Big Tobacco has long understood this, and hence it is perhaps no surprise that these firms, combined, spend 26 million dollars per day in marketing ${ }^{59}$. Research demonstrates that smokers ascribe characteristics to known brands and types of cigarettes $^{60-62}$, even when unknowingly comparing identical products ${ }^{60}$.

Concerns about Big Tobacco starting to exploit such concerns through 'greenwashing' are well founded. Evidence already exists of the industry exploring Social Life Cycle Assessment ${ }^{63}$, and the apparent engagement of the industry with Corporate Social Responsibility (CSR) has drawn many negative comments ${ }^{64-67}$. Chapman has written eloquently about Big Tobacco's apparent engagement with CSR using the metaphor of a wolf in sheep's clothing ${ }^{64}$. It is interesting to note that Chapman is not alone in his cynical evaluation of tobacco companies use of $\mathrm{CSR}^{65}$, with the World Health Organization going so far as to declare that there is an inherent contradiction between tobacco companies and corporate social responsibility ${ }^{67}$.

The best current example of attempts to describe cigarettes as 'natural' and 'organic' is probably the case of the Santa Fe Natural Tobacco Company, which produces Natural American Spirit cigarettes. In early 2017 , the company was required to remove the terms 'additive-free' and 'natural' from its marketing materials by the US Food and Drug Administration (FDA). However, the producer is still able to retain the use of the word 'Natural' in its brand name. In addition, the company is still able to use the term 'organic' in its marketing, as well as implying the 'healthy' nature of its product through the use of its ingredients list, viz. 'Tobacco Ingredients: Tobacco and Water ${ }^{68}$.

Current European Union legislation explicitly prevents the marketing of tobacco products as environment friendly ${ }^{20}$. However, the threat remains of a tobacco company developing a brand and/or a variant name that implies an enhanced environmental sensitivity. At present, even under plain packaging legislation, tobacco manufacturers are legally still entitled to display the Brand name of their product and then on the line underneath the Variant name. A tobacco manufacturer seeking to market their 'green' credentials could therefore create a brand called for example 'Mother Earth' (English) or its equivalents 'Gaia' (Greek), 'Terra' (Roman), or 'Jord' (Norse). To further promulgate an environment-friendly image, variant names such as 'Green Leaf', 'Blossom' or 'Eco' could be used.

However, even within the European Union, current tobacco-control legislation does not cover social/equity-based labelling. Thus, Big Tobacco could potentially include logos or launch new brands 
and variants of cigarettes focusing on issues such as fair wages, or possibly social investment in schools or health systems for workers, their families and communities. This could essentially be akin to current Fair Trade marketing. Even in countries that have introduced plain packaging legislation, a tobacco firm seeking to exploit this avenue of promotion could therefore potentially create a brand called something akin to 'Workers Paradise' with brand variations such as 'Equity', 'Solidarity' or 'Comrade'. It should be noted that a significant increase in Variant names on cigarettes was noted in Australia after the introduction of plain packaging ${ }^{69,70}$. Similarly, tobacco firms in the US have been observed to introduce Variant names in an effort to exploit loopholes in the FDA ban on terms such as 'light' and 'mild'. Firms are known to use colour-based terms, such as silver to indicate lightand mild-strength cigarettes ${ }^{71}$.

It is highly unlikely that the Brand and Variant names alone would have a significant impact on the marketing success of such initiatives. However, although strict controls on tobacco advertising and sponsorship exist in countries such as Australia, New Zealand and Member States of the European Union, control of online and social media marketing may be an Achilles heel in such regulation, particularly given the significant growth in the average amount of time people spent using such technologies ${ }^{72-74}$. National borders and local legislation mean little in an increasing online and virtual world.

In relation to the evolving and deceptive nature of tobacco marketing, it is important to remember the Marlboro Formula 1 (F1) logo controversy. Philip Morris began funding the Ferrari F1 team in 1968 to promote the Marlboro brand ${ }^{75,76}$. After many years of significant and public funding, the 2005 European Union Tobacco Advertising Directive prohibited such overt sponsorship, in line with recommendations of the Framework Convention on Tobacco Control (FCTC). However, funding by Philip Morris continued, and although the Marlboro logo ostensibly disappeared, it continued covertly with a 'Barcode' design that has been neatly described as a form of 'alibi' marketing. Although Ferrari claimed that the new design was simply part of the livery of the car, it was obvious that the location, colours and design of the logo could not fool anyone and was eventually withdrawn ${ }^{75}$. Tobacco industry funding of the team has continued and it could justifiably be argued that the red Ferrari F1 car and Marlboro are currently synonymous to many older smokers.

The creativity of firms to circumvent bans on advertising is also evident in the parallel sector of alcohol control. This is evident in tactics adopted by the Welsh brewery Brains, which has sponsored the Welsh rugby team since 2004 . In 2005 , in response to French legislation that prohibits alcohol sponsorship of televised games played on French soil, the 'Loi Évin', the Welsh team played in jerseys reading 'Brawn' rather than 'Brains'. In 2007, the club again played in France, this time sporting jerseys reading 'Brawn Again'77,78.

\section{CONCLUSION}

Regulation of tobacco remains weak in many countries, including leading economies such as China and the USA. In such loosely regulated environments, the potential for the adoption of ecological and social/equity-based marketing is obvious. In countries with stricter legislation there is no room for complacency. The tobacco industry is well known for its ingenious marketing techniques and its hydra-like ability to respond aggressively to attempts to rein in and control its activities. It is imperative, therefore, that legislation is introduced to prevent exploitation of loopholes.

\section{REFERENCES}

1. World Health Organization. WHO Report on the Global Tobacco Epidemic, 2013: Enforcing bans on tobacco advertising, promotion and sponsorship. http://apps.who.int/iris/bitstream/ handle/10665/85380/9789241505871_eng. pdf;jsessionid=F3E57A5DE2CD822C33CF 71AC 2DCD592E?sequence=1. Published 2013 . Accessed May 31, 2018.

2. GBD 2015 Tobacco Collaborators., et al. Smoking prevalence and attributable disease burden in 195 countries and territories, 1990-2015: a systematic analysis from the Global Burden of Disease Study 2015. Lancet. 2017;13(389). doi:10.1016/S0140-6736(17)30819-X

3. World Health Organisation. Report on the Global Tobacco Epidemic, 2008: The MPOWER package. http://apps.who.int/iris/bitstream/ handle/10665/43818/9789241596282_eng. pdf?sequence=1. Published 2008. Accessed May 31, 2018.

4. Stephen SL, Theo V, Flaxman AD, Goodarz D, Kenji $\mathrm{S}$, Healther AR, et al. A comparative risk assessment of burden of disease and injury attributable to 67 risk 
factors and risk factor clusters in 21 regions, 19902010: a systematic analysis for the Global Burden of Disease Study 2010. Lancet. 2012;380(9859):2224-60. doi:10.1016/S0140-6736(12)61766-8

5. Steinberg ML, Williams JM, Ziedonis DM. Financial implications of cigarette smoking among individuals with schizophrenia. Tobacco Control. 2004;13:206.

6. World Health Organization. Tobacco and its impact: an overview. http://apps.who.int/iris/bitstream/ handle/10665/255574/9789241512497-eng. pdf? sequence=1 Published 2017. Accessed May 31, 2018.

7. Lecours N, Almeida GEG, Abdallah JM, Novotny TE. Environmental health impacts of tobacco farming: a review of the literature. Tobacco Control. 2012; 21:191196. doi10.1136/tobaccocontrol-2011-050318

8. Öberga M, Woodwardb A, Jaakkolac MS, Perugad A, Prüss-Ustüne A. Global estimate of the burden of disease from second-hand smoke. http://www.who.int/ tobacco/publications/second_hand/global_estimate_ burden_disease/en/. Published 2010. Accessed May 31, 2018.

9. Acuff L, Fristoe K, Hamblen J, Smith M, Chen J. Third-Hand Smoke: Old Smoke, New Concerns. J Community Health. 2016;41(3):680-7. doi:10.1007/s10900-015-0114-1.

10. Mahabee-Gittens EM, Merianos AL, Matt GE. Preliminary evidence that high levels of nicotine on children's hands may contribute to overall tobacco smoke exposure. Tobacco Control. 2018;27(2):217219. doi:10.1136/tobaccocontrol-2016-053602

11. Wallbank LA, MacKenzie R, Beggs PJ. Environmental impacts of tobacco product waste: International and Australian policy responses. Ambio. 2017;46(3): 361370. doi:10.1007/s13280-016-0851-0

12. Novotny TE, Aguinaga Bialous S, Burt L, Curtis C, Luiza da Costa V, Usman Iqtidar S, et al. The environmental and health impacts of tobacco agriculture, cigarette manufacture and consumption. Bulletin of the World Health Organization. 2015;93(12)877-880. doi:10.2471/BLT.15.152744.

13. Novotny TE, Kristen L, Smith E, Wang V, Barnes R. Cigarettes butts and the case for an environmental policy on hazardous cigarette waste. International Journal of Environmental Research in Public Health. 2009;6(5):1691-1705. doi:10.3390/ijerph6051691

14. Novotny TE, Slaughter E. Tobacco Product Waste: An Environmental Approach to Reduce Tobacco Consumption. Curr Environ Health Rep. 2014;6(1):208216. doi:10.1007/s40572-014-0016-x

15. Novotny TE, Zhao F. Consumption and production waste: another externality of tobacco use. Tobacco Control. 1999;8(1):75-80. doi:10.1136/tc.8.1.75

16. Slaughter E, Gersberg RM, Wantanabe K, Rudolph J, Stransky C, Novotny TE. Toxicity of cigarette butts, and their chemical components, to marine and freshwater fish. Tobacco Control. 2011;20(Suppl 1):i25-29. doi:10.1136/tc.2010.040170

17. Zafeiridou M, Hopkinson NS, Voulvoulis N. Cigarette smoking: an assessment of tobacco's global environmental footprint across its entire supply chain, and policy strategies to reduce it. Geneva: World Health Organization; 2018.

18. World Health Organisation. Framework Convention on Tobacco Control. http://apps.who.int/iris/bitstream/ handle/10665/42811/9241591013.pdf;jsessionid=CFA C A 8 A B A 796606 B 92139 C C 82 B C 66 A F E? sequence $=1$ Published 2005. Accessed May 31, 2018.

19. Henriksen L. Comprehensive tobacco marketing restrictions: promotion, packaging, price and place. Tobacco Control. 2012;21(2):147-153. doi:10.1136/tobaccocontrol-2011-050416.

20. European Union. Tobacco Products Directive. Directive 2014/40/EU of the European Parliament and of the Council of 3 April 2014 on the approximation of the laws, regulations and administrative provisions of the Member States concerning the manufacture, presentation and sale of tobacco and related products and repealing Directive 2001/37/EC Text with EEA relevance. https://eur-lex.europa.eu/legal-content/EN/ TXT/?uri=CELEX:32014L0040. Published April 24, 2014. Accessed May 31, 2018.

21. Joosens L, Raw M. The Tobacco Control Scale 2016 in Europe. Brussels: Association of European Cancer Leagues; 2017.

22. Glantz SA, Slade J, Bero LA, Peter Hanauer, Barnes DE. The Cigarette Papers. 1st ed. London: University of California Press; 1998.

23. Grüning T, Gilmore AB, McKee M. Tobacco Industry Influence on Science and Scientists in Germany. American Journal of Public Health. 2006;96(1):20-32. doi:10.2105/AJPH.2004.061507

24. Kluger R. Ashes To Ashes. America's Hundred-Year Cigarette War, the Public Health, and the Unabashed Triumph of Philip Morris. New York: Vintage Books; 1996.

25. Michaels D. Doubt is Their Product: How Industry's Assault on Science Threatens Your Health. New York: Oxford University Press; 2008.

26. Proctor RN. Golden Holocaust: Origins of the Cigarette Catastrophe and the Case for Abolition. Berkeley: University of California Press; 2011.

27. Orestes N, Conway EM. Merchants of Doubt: How a handful of Scientists Obscured the Truth on Issues from Tobacco Smoke to Global Warming. London: Bloomsbury Press; 2010.

28. Brandt AM. Inventing Conflicts of Interest: A History of Tobacco Industry Tactics. American Journal of Public Health. 2012;102(1):63-71. doi:10.2105/AJPH.2011.300292

29. Fallin A, Grana R, Glantz SA. 'To quarterback behind 
the scenes, third-party efforts': the tobacco industry and the Tea Party. Tobacco Control. 2014;23: 322-331. doi:10.1136/tobaccocontrol-2012-050815

30. Francey N, Chapman S. "Operation Berkshire": the international tobacco companies' conspiracy. BMJ. 2000;321(7257):371-374. doi:10.1136/bmj.321.7257.371

31. Milberger S, Davis RM, Douglas CE, et al. Tobacco manufacturers' defence against plaintiffs' claims of cancer causation: throwing mud at the wall and hoping some of it will stick. Tobacco Control. 2006;15(iv):1726. doi:10.1136/tc.2006.016956

32. Proctor RN. "Everyone knew but no one had proof": tobacco industry use of medical history expertise in US courts, 1990-2002. Tobacco Control. 2006;15:iv117iv125. doi:10.1136/tc.2004.009928

33. Proctor RN. The history of the discovery of the cigarettelung cancer link: evidentiary traditions, corporal denial, global toll. Tobacco Control. 2012;21(2):87-91. doi:10.1136/tobaccocontrol-2011-050338

34. Gilmore AB, Fooks G, Drope J, Bialous SA, Rachel R. Jackson. Exposing and addressing tobacco industry conduct in low- income and middle-income countries. The Lancet. 2015; 385(9972):1029-1043. doi:10.1016/S0140-6736(15)60312-9

35. Gilmore AB, McKee M. Moving East: how the transnational tobacco industry gained entry to the emerging markets of the former Soviet Union - part 1: establishing cigarette imports. Tobacco Control. 2004a;13(2):143-150. doi:10.1136/tc.2003.005108

36. Gilmore AB, McKee M. Moving East: how the transnational tobacco industry gained entry to the emerging markets of the former Soviet Union part II: an overview of priorities and tactics used to establish a manufacturing presence. Tobacco Control. 2004b;13(2):151-160. doi:10.1136/tc.2003.005207

37. Kline N. No Logo. London: Picador; 1999.

38. Brécard D, Hlaimi B, Sterenn L, Perraudeau Y, Salladarré F. Determinants of demand for green products: An application to eco-label demand for fish in Europe. Ecological Economics. 2009;69:115-125. doi:10.1016/j.ecolecon.2009.07.017

39. Mario F, Teisl BR, Hicks RL. Can Eco-Labels Tune a Market? Evidence from Dolphin-Safe Labelling. Journal of Environmental Economics and Management. 2002;43, 339-359. doi:10.1006/jeem.2000.1186

40. Randjelovic J, Anastasia R, O'Rourke R, Orsato J. The emergence of green venture capital. Business Strategy \& the Environment. 2003;12(4):240-253. doi:10.1002/bse.361

41. Hartlieb S, Jones B. Humanising Business through ethical labelling: Progress and Paradoxes in the UK. Journal of Business Ethics. 2009;88(3):583-600. doi:10.1007/s10551-009-0125-x

42. Winge TM. "Green Is the New Black": Celebrity Ghic and the "Green" Commodity Fetish.
Journal of fashion theory. 2008;12(4):511-523. doi:10.2752/175174108X346968

43. Thomas S. From "Green Blur" to Ecofashion: Fashioning an Eco-lexicon. Journal of Fashion Theory. 2008; 12(4):525-539. doi:10.2752/175174108X346977

44. Guillermo M. The Apparel Industry Partnership's Free Labor Association: A Solution to the Overseas Sweatshop Problem or the Emperor's New Clothes. Journal of International Law \& Politics. 1999;32(1):1059-1175.

45. Hartlieb S, Jones B. Humanising Business Through Ethical Labelling: Progress and Paradoxes in the UK. Journal of Business Ethics. 2009;88:583-600. doi:10.1007/s10551-009-0125-x

46. Murphy A, Jenner-Leuthart B. "Fairly sold? Adding value with fair trade coffee in cafes", Journal of Consumer Marketing. 2011;28(7):508-515. doi: 10.1108/07363761111181491

47. Oliver Balch. Child labour can't be carpeted over by a logo, but it's a step in the right direction. The Guardian Newspaper. https://www.theguardian.com/globaldevelopment/2013/aug/15/child-labour-productcertification. Published 15 August, 2013. Accessed June $7,2018$.

48. Tansy Hoskins. Child free fashion: a new label aims to end exploitation. The Guardian Newspaper. https:// www.theguardian.com/sustainable-business/2015/ jul/31/child-free-fashion-new-label-end-exploitation. Published July 31, 2015. Accessed June 7, 2018.

49. ChowdhryG and Beeman M. Challenging Child Labor: Transnational Activism and India's Carpet Industry. The ANNALS of the American Academy of Political and Social Science. 2001;575(1):158-175. doi:10.1177/000271620157500110

50. Grant JA, Taylor I. Global governance and conflict diamonds: The Kimberley Process and the quest for clean gems. The Round Table. 2004;93(375):385-401. doi:10.1080/0035853042000249979

51. Le Billon P. Fatal transactions: Conflict diamonds and the (anti) terrorist consumer. Antipode. 2006;38(4):778801. doi:10.1111/j.1467-8330.2006.00476.x

52. Santiago AP. Guaranteeing conflict free diamonds: From compliance to norm expansion under the Kimberley Process Certification Scheme. South African Journal of International Affairs. 2014;21(3):413-429. doi:10.1080/10220461.2014.972441

53. Miele M. The taste of happiness: free-range chicken. Environment and Planning A. 2001;43:2076-2090. doi:10.1068/a43257

54. Wycherley I. Greening supply chains: the case of The Body Shop International. Business Strategy and the Environment. 1999;8(2):120-127. doi:10.1002/ ( SICI ) $1099-0836$ ( $199903 / 04) 8: 2<120:$ :AID BSE188>3.0.CO;2-X

55. Broberg O. Labelling the Good: Alternative Visions and 
Organic Branding in Sweden in the Late Twentieth Century. Enterprise \& Society. 2010;11(4):811-838. doi:10.1093/es/khq094

56. Huffman WE, McCluskey JJ . The Economies of Labelling GM Foods. The Journal of Agrobiotechnology Management \& Economics. 2014;17(2):156-160. http:// www.agbioforum.org. Accesed September 2018.

57. Harris SM. "Green Tick ${ }^{\mathrm{TM}}$ : an example of sustainability certification of goods and services", Management of Environmental Quality: An International Journal. 2007; 18(2):167-178. doi:10.1108/14777830710725830

58. Sarkar AN. Green Branding and Eco-innovations for Evolving a Sustainable Green Marketing Strategy. AsiaPacific Journal of Management Research and Innovation. 2012;8(1):39-58. doi:10.1177/2319510X1200800106

59. Truth Initiative (2018) Marketing. https:// truthinitiative.org/topics/industry-and-influences/ marketing. Accessed September 2018.

60. Skaczkowski G, Durkin S, Kashima Y, Wakefield M. "Influence of premium vs masked cigarette brand names on the experienced taste of a cigarette after tobacco plain packaging in Australia: an experimental study". BMC Public Health. 2018;18(1):295. doi:10.1186/s12889-018-5200-8

61. Friedman HH, Dipple WS. The effect of masculine and feminine brand names on the perceived taste of a cigarette. Decis Sci. 1978;9(3):467-471. doi:10.1111/j.1540-5915.1978.tb00735.x

62. Skaczkowski G, Durkin S, Kashima Y, Wakefield M. Influence of premium versus value brand names on the smoking experience in a plain packaging environment: an experimental study. BMJ Open 2017;7(1):e014099. doi:10.1136/bmjopen-2016-014099.

63. GABI Software. (nd). Customer Detail: British American Tobacco. http://www.gabi-software.com/customers/ customers-detail/article/british-american-tobacco/. Published N/A. Accessed June 7, 2018.

64. Chapman S. Advocacy in action: extreme corporate makeover interruptus: denormalising tobacco industry corporate schmoozing. Tobacco Control. 2004; 13: 445447. doi: 10.1136/tc.2004.010025

65. LC Friedman. Tobacco industry use of corporate social responsibility tactics as a sword and a shield on secondhand smoke issues. J Law Med Ethics. 2009;37(4):819-827. doi: 10.1111/j.1748-720X.2009.00453.x

66. Hirschhorn N. Corporate social responsibility and the tobacco industry: hope or hype? Tobacco Control. 2004;13:447-453. doi:10.1136/tc.2003.006676

67. World Health Organization. Tobacco industry and corporate responsibility...an inherent contradiction. http://www.who.int/tobacco/media/en/tob-industry. pdf. Published February, 2013. Accessed June 7, 2018.

68. Truth Initiative (2017) Agreement on American Spirit cigarettes fails to protect public from misleading claims. https://truthinitiative.org/news/agreement-american- spirit-cigarettes-fails-protect-public-misleading-claims. Accessed September 2018.

69. Greenland SJ. Gigarette brand variant portfolio strategy and the use of colour in a darkening market. Tob Control. 2015;24(e1):e65-71. doi:10.1136/tobaccocontrol-2013-051055

70. Greenland SJ. The Australian experience following plain packaging: the impact on tobacco branding. Addiction.2016; 111(12):2248-2258. doi:10.1111/add.13536

71. Connolly GN, Alpert HR. Has the tobacco industry evaded the FDA's ban on 'Light' cigarette descriptors? Tobacco Control. 2014;23(2):140-5. doi:10.1136/tobaccocontrol-2012-050746

72. Campaign for Tobacco-Free Kids. Tobacco Product Marketing on the Internet. https://www. tobaccofreekids.org/assets/factsheets/0081.pdf. Published Arpil 10, 2018. Accessed June 7, 2018.

73. Jackler RK, Li VY, Cardiff RAL, Ramamurthi D. Promotion of tobacco products on Facebook: policy versus practice. Tobacco Control. 2018. doi:10.1136/tobaccocontrol-2017-054175

74. Freeman B, Chapman S. Open source marketing: Camel cigarette brand marketing in the "Web 2.0" world. Tobacco Control. 2009;18(3):212-7. doi:10.1136/tc.2008.027375

75. Grant-Braham B, Britton J. Motor racing, tobacco company sponsorship, barcodes and alibi marketing. Tobacco Control. 2012;21(6):529-35. doi:10.1136/tc.2011.043448

76. Shatenstein S. Canada: chicanery in the chicanes. Tobacco Control. 2004;13: 213-214. PMID: 15333867

77. Purves RI, Critchlow N, Stead M. Foul Play? Alcohol Marketing During UEFA EURO 2016. http://www.ias. org.uk/uploads/pdf/IAS\%20reports/rp24042017.pdf. Published April, 2017. Accessed June 7, 2018.

78. A Maclean, J Bonington. Legal and regulatory updatesSports sponsorship in the UK: The impact of regulatory intervention. Journal of Sponsorship. 2008;1(4):380387.

CONFLICTS OF INTEREST

Authors have completed and submitted the ICMJE Form for Disclosure of Potential Conflicts of Interest and none was reported.

FUNDING

There was no source of funding for this research.

PROVENANCE AND PEER REVIEW

Not commissioned; externally peer reviewed. 